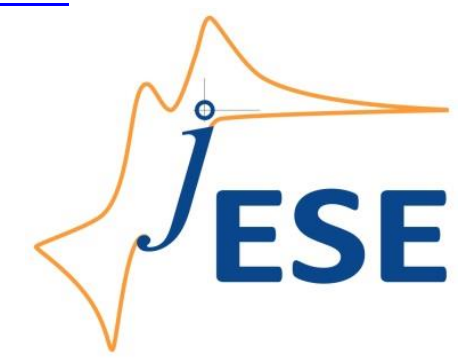

Open Access: ISSN 1847-9286

www.jESE-online.org

Original scientific paper

\title{
Electrochemical treatment of dye wastewater using nickel foam electrode
}

\author{
Kaavya Muthumanickam, Ramanujam Saravanathamizhan ${ }^{凶}$ \\ Department of Chemical Engineering, A.C. Tech Anna University, Chennai-600025, India \\ Corresponding author: thamizhan79@rediffmail.com; Tel +91 4422359237 \\ Received: May 28, 2021; Revised: July 5, 2021; Accepted: July 10, 2021; Published: July 16, 2021
}

\begin{abstract}
Removal of dye from wastewater has been investigated using the electrocoagulation method. Batch experiment has been conducted to remove the color from synthetically prepared Acid Red 87 dye wastewater. Stainless steel and nickel foam sheets are used as cathode and anode, respectively. The effect of some operating parameters, such as current density, initial dye concentration and supporting electrolyte concentration, on color removal has been studied. It can be observed from the present investigations that the nickel foam electrode effectively removes color from the wastewater. Nickel hydroxyl species formed during the operation and also, nickel(II) hydroxide flocs formed in a subsequent stage, trap colloidal precipitates and make solid-liquid separation easier during the flotation stage. These stages of electrocoagulation must be optimized to design an economically feasible process.
\end{abstract}

\section{Keywords}

Acid Red 87, color removal, electrocoagulation, kinetics, wastewater

\section{Introduction}

Wastewaters generated from various process industries contain various types of pollutants. These pollutants must be treated, and only clean water must be disposed to the environment. Industries such as textile, paper and pulp, as well as leather and pharmaceutical industries, are generating large amounts of pollutants. Distinct pollutant treatment techniques have already been adopted for the wastewater treatment, namely physical, chemical and biological techniques. Pollutants coming out from the textile industry contain organics and colours, and treatment of these pollutants is mandatory before letting them to the environment [1].

In this aspect, the cost-effective treatment techniques are ultimately required to treat a wide range of wastewater pollutants in a diverse range of conditions. Compared with conventional treatment techniques, electrocoagulation method of pollutant removal provides a robust and 
efficient treatment method. Electrocoagulation is usually used to treat textile wastewater [2], dairy wastewater [3], paper industry effluent [4], printing wastewater [5], metal finishing [6] and plating wastewater [7], pharmaceutical wastewater [8], etc.

In the electrocoagulation process a sacrificial metal anode is used for the electrochemical reaction that provides active metal cations for the coagulation process. The advantage of electrocoagulation is that coagulants are generated in situ, i.e. they are not added externally to the wastewater. Electrodes such as aluminium and iron are widely used for the electrocoagulation process [9]. Electrocoagulation of textile wastewater was studied using Al-Fe anode by Ghanbari et al. [10]. The authors reported that $98 \%$ color removal efficiency was achieved using this combined anode. Safwat [5] performed the electrocoagulation process for the treatment of real printing wastewater using two different, zinc and titanium electrodes. With the electrode distance of $4 \mathrm{~cm}$, the author observed 47 and $41 \%$ chemical oxygen demand (COD) removal using titanium and zinc electrode, respectively. Devlin et al. [11] studied the influents from municipal wastewater treatment plant, which were electrochemically treated with sacrificial aluminum, iron, and magnesium electrodes. It was noticed that aluminum and iron electrodes remove 68 \% COD, while magnesium electrodes, removed $49 \%$ COD. Electrocoagulation of metal fining wastewater was studied by llhan et al. [12], where the authors reported the importance of $\mathrm{pH}$ adjustment after the electrocoagulation process using iron electrodes, which are found $10 \%$ more effective than aluminum electrodes.

Nickel has been also used as a sacrificial anode for the wastewater treatment. Karikaningsih et al. [13] performed electrocoagulation using metallic Ni foam anode for the removal of boron present in wastewater. The authors reported that removal efficiency was maximized at $\mathrm{pH} 8-9$, and decreased as $\mathrm{pH}$ increased beyond this range. Nickel foam electrode has also been used for electrooxidation of wastewater. Ni-foam coated with iron-chitosan solution was designed as a new cathode for the electro-Fenton treatment of colored effluents [14]. The authors concluded that new cathode is a suitable alternative for the treatment of colored wastewater by continuous electro-Fenton treatment. Similar studies have been also reported $[15,16]$, showing that Ni-foam cathode is suitable for the treatment of colored wastewater by continuous electro-Fenton treatment.

Nickel foam is a three-dimensional electrode, with many advantages including good electrical conductance and high specific surface area. In literature data, however, very few authors have used $\mathrm{Ni}$-foam for electrocoagulation process. Hence in the present study, we are focused to remove Acid Red 87 dye from the simulated textile wastewater using nickel foam electrode.

\section{Experimental}

\section{Chemicals}

Acid Red 87 dye and other chemicals were purchased from SRL Pvt Ltd., Chennai and used without any purification. The dye, also called Eosin yellow has the molecular formula of $\mathrm{C}_{20} \mathrm{H}_{6} \mathrm{Br}_{4} \mathrm{Na}_{2} \mathrm{O}_{5}$. Known amount of Acid Red 87 dye was dissolved in distilled water to prepare the synthetic wastewater. Concentration of $\mathrm{NaCl}$ was varied by adding required amount of salt into prepared dye solution. $\mathrm{pH}$ of the solution was adjusted by dropwise adding either alkali or acid (1 M) solution.

\section{Electrochemical experiments}

The electrochemical setup consisted of $100 \mathrm{ml}$ capacity cell, filled with the prepared synthetic wastewater solution and two immersed electrodes. The schematic setup of the experiment is shown in Figure 1. The electrolytic solution was stirred throughout with the help of magnetic stirrer during the process. Batch experiments were conducted using a digital DC regulated power supply, having 
the range 0-30 $\mathrm{V}$ and 0-5 A. Stainless steel sheet was used as cathode and nickel foam as anode. The electrodes having total active electrode area of $14 \mathrm{~cm}^{2}$ were placed vertically into solution, parallel to each other at a distance of $1 \mathrm{~cm}$, and connected to a DC power supply.

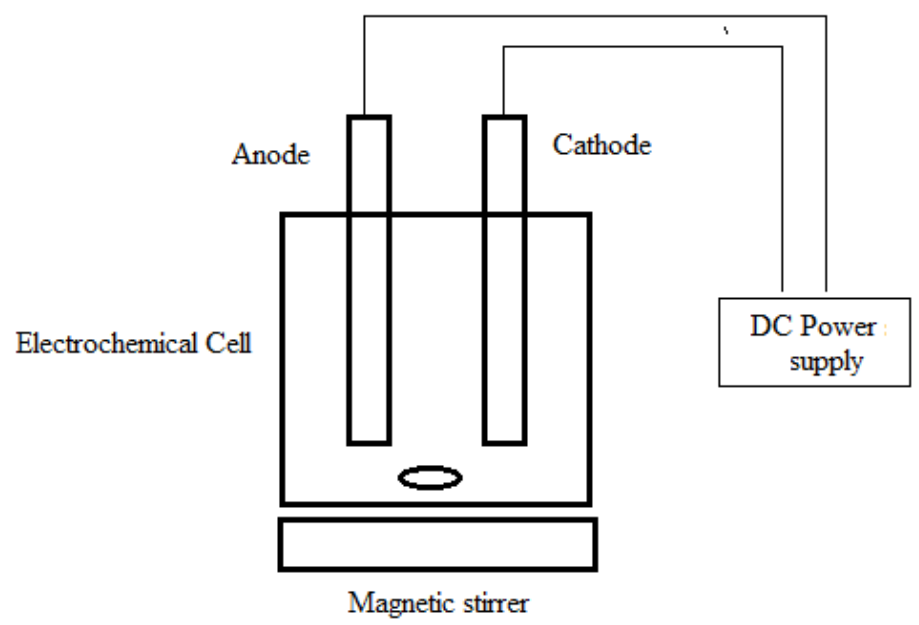

Figure 1. Scheme of experimental setup

A metallic foam used as a sacrificial electrode does not only catalytically alter the energy barrier to the electron transfer to form metal hydroxides, but also provides a large surface area where the redox reaction proceeds. Therefore, nickel foam is an attractive material owing to its high specific capacitance, well-defined electrochemical activity and high stability.

In the electrocoagulation process, the main reactions occurring at the electrodes involving $\mathrm{Ni}$ anode are:

Anode:

$$
\mathrm{Ni}(\mathrm{s}) \rightarrow \mathrm{Ni}^{2+}{ }_{(\mathrm{aq})}+2 \mathrm{e}^{-}
$$

Cathode:

$$
\begin{aligned}
& 2 \mathrm{H}_{2} \mathrm{O}+2 \mathrm{e}^{-} \rightarrow \mathrm{H}_{2(\mathrm{~g})}+2 \mathrm{OH}^{-}(\mathrm{aq}) \\
& \mathrm{Ni}^{2+}{ }_{(\mathrm{aq})}+2 \mathrm{OH}^{-}{ }_{(\mathrm{aq})} \rightarrow \mathrm{Ni}(\mathrm{OH})_{2(\mathrm{~s})}
\end{aligned}
$$

Overall reaction: $\mathrm{Ni}_{(\mathrm{s})}+2 \mathrm{H}_{2} \mathrm{O} \rightarrow \mathrm{Ni}(\mathrm{OH})_{2(\mathrm{~s})}+\mathrm{H}_{2(\mathrm{~g})}$

$\mathrm{Ni}$ is oxidized at anode by reaction (1), water is reduced at cathode by reaction (2), while dissolved $\mathrm{Ni}^{2+}$ ions form Ni-hydroxide species by reaction (3). The overall reaction (4) suggests a removal mechanism by formation of $\mathrm{Ni}(\mathrm{OH})_{2}$ of high adsorption properties for dye bonding and subsequent coagulation and precipitation. Depending upon $\mathrm{pH}$ of an aqueous medium, different electrolytic forms can be generated like $\mathrm{NiOH}, \mathrm{Ni}(\mathrm{OH})_{2}, \mathrm{Ni}(\mathrm{OH})^{-} 3, \mathrm{Ni}(\mathrm{OH})^{2}$, and $\mathrm{Ni}_{4}(\mathrm{OH})_{4}$, suggesting that $\mathrm{pH}$ of the electrolyte governs precipitation. At higher $\mathrm{pH}$ values, $\mathrm{NiO}, \mathrm{NiOOH}$, or $\mathrm{Ni}(\mathrm{OH})_{3}$ can be also formed at specific overpotentials. The formed $\mathrm{Ni}(\mathrm{OH})_{2(\mathrm{~s})} / \mathrm{NiOOH}$ appear as sweep flocs with large surface area, which favor adsorption and thus removal of pollutants. Nickel oxide was proven to be a good adsorbent for the treatment of organic and inorganic wastewaters.

\section{Experimental procedure}

The experiments were performed at room temperature and constant stirring speed of $250 \mathrm{rpm}$. In each run, $100 \mathrm{ml}$ of synthetic wastewater dye solution was placed into the electrolytic cell. The current density was adjusted to a desired value for the experiment. At the end of the run, the solution was filtered, and the filtrate was centrifuged at $200 \mathrm{rpm}$. Before each run, organic impurities on electrode surfaces were removed by washing with acetone, while the surface oxide layer was removed by dipping for $5 \mathrm{~min}$ in dilute hydrochloric acid. At the end of the experiment, the electrodes were washed thoroughly with water to remove any solid residues on the surfaces, 
dried, and reweighed. Operating parameters such as initial dye concentration, supporting electrolyte concentration and current density were varied to study the color removal of dye wastewater at initial $\mathrm{pH}$ value of 7 and distance between electrodes of $1 \mathrm{~cm}$ in all experiments.

\section{Analytical method}

Samples of dye solution were analyzed using a UV-Spectrophotometer at $\lambda_{\max }(518 \mathrm{~nm}$ of Acid Red 87). The percentage of color removal was calculated according to [17]:

$$
\text { Removal }=\frac{\text { initial absorbance }- \text { final absorbance }}{\text { initial absorbance }} 100
$$

Initial and final absorbances in equation (5), are absorbances measured at $\lambda_{\max }$ initially and after treatment time $(t)$.

\section{Result and discussion}

\section{Kinetic of decolorization}

The rate of decolorization reaction in a batch reactor can be described as the first order kinetics [17]:

$$
\ln \frac{C}{C_{0}}=-k t
$$

where $C_{0}$ and $C$ are initial dye concentration and dye concentration after reaction time $t$, while $k$ is the reaction rate constant. From the linear plot $-\ln \left(C / C_{0}\right) v s$. $t$, the rate constant can be determined from its slope. The rate constants of dye wastewater decolorization for different dye concentrations are given in Table 1, where it can be noticed that the rate constant decreases from 0.1232 to $0.0171 \mathrm{~min}^{-1}$ with increasing dye concentration.

Table 1. Decolorization kinetics of dye wastewater at different concentrations of dye

\begin{tabular}{cc}
\hline Initial dye concentration, $\mathrm{mg} \mathrm{L}^{-1}$ & $\mathrm{k} / \mathrm{min}^{-1}$ \\
\hline 100 & 0.1232 \\
\hline 300 & 0.0332 \\
\hline 500 & 0.0171 \\
\hline
\end{tabular}

\section{Effect of supporting electrolyte concentration}

The effect of the concentration of supporting electrolyte $(\mathrm{NaCl})$ on dye removal is shown in Figure 2.

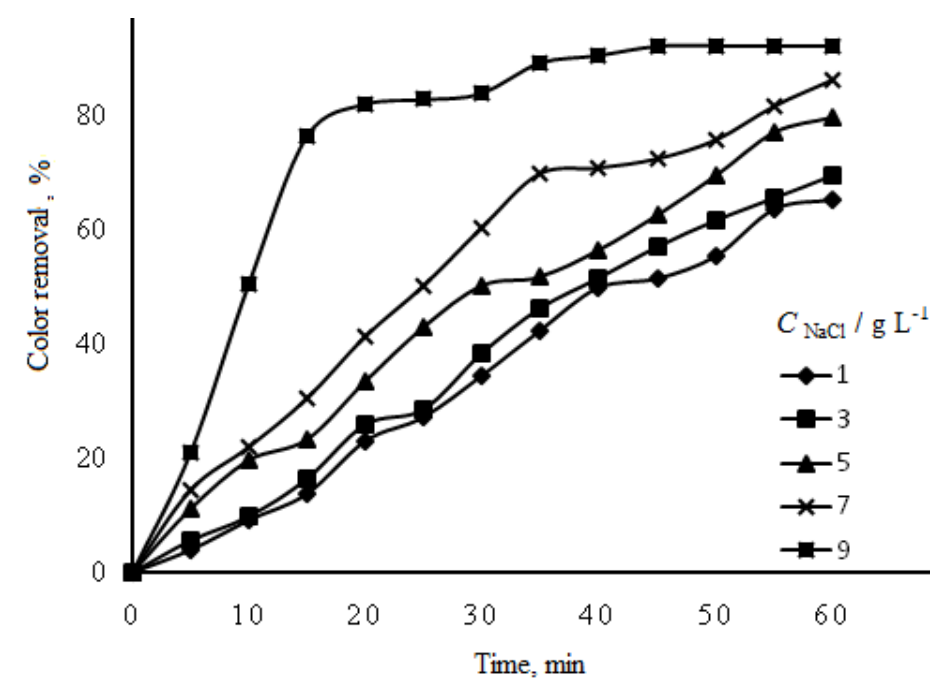

Figure 2. Effect of supporting electrolyte (NaCl) concentration (1-9 $\left.\mathrm{g} \mathrm{L}^{-1}\right)$ on dye removal. Initial dye concentration: $100 \mathrm{mg} \mathrm{L}^{-1}$; current density: $12 \mathrm{~mA} \mathrm{~cm} \mathrm{~cm}^{-2}$; 7.0 
The supporting electrolyte $\mathrm{NaCl}$ concentrations were varied from 1 to $9 \mathrm{~g} \mathrm{~L}^{-1}$ and the color removal was observed. It can be noticed from Figure 2 that color removal efficiency increased not only with the reaction time, but with increase in the concentration of $\mathrm{NaCl}$ too. This is probably due to the generation of hypochlorite ions $\left(\mathrm{OCl}^{-}\right)$formed together with hypochlorous acid $(\mathrm{HOCl})$ by electrolysis of near-neutral aqueous $\mathrm{NaCl}$ solutions. Presence of $\mathrm{OCl}^{-}$ions in wastewater enhances the formation of nickel hydroxide. Increase in the quantity of the supporting electrolyte results in producing of larger amount of sludge during the electrocoagulation process [18]. The sludge generated during the experiment was minimal and safely removed in each experiment and disposed.

\section{Effect of current density}

Current density is important operating parameter in batch electrocoagulation process, since it is the only parameter that can control the removal process directly. Electrode distance and $\mathrm{pH}$ of the solution were fixed for the present experiment and the current density is varied. Current density directly determines both coagulant dosage and bubble generation rates, and for higher current density, the shorter treatment time is required for dye removal. This is ascribed to the fact that at high current density, the dissolution of nickel anode increases, resulting in a greater amount of $\mathrm{Ni}$ hydroxide for the removal of dyes pollutants. The effect of current density on color removal is shown in Figure 3. Current density was varied from 3 to $12 \mathrm{~mA} \mathrm{~cm}$, and color removal was observed. It is noticed from Figure 3 that color removal increases with increase in the current density. The decolorization efficiency increases rapidly up to $92 \%$ at the current density of $12 \mathrm{~mA} \mathrm{~cm}^{-2}$, and then it remains almost constant for higher current densities [19]. The dissolved amount of anode is fairly linearly dependent on the current density. High current density increases the coagulant generation with lesser size which provides larger surface area between the coagulant and pollutants. Increase in the current density decreases the treatment time of the dye solution.

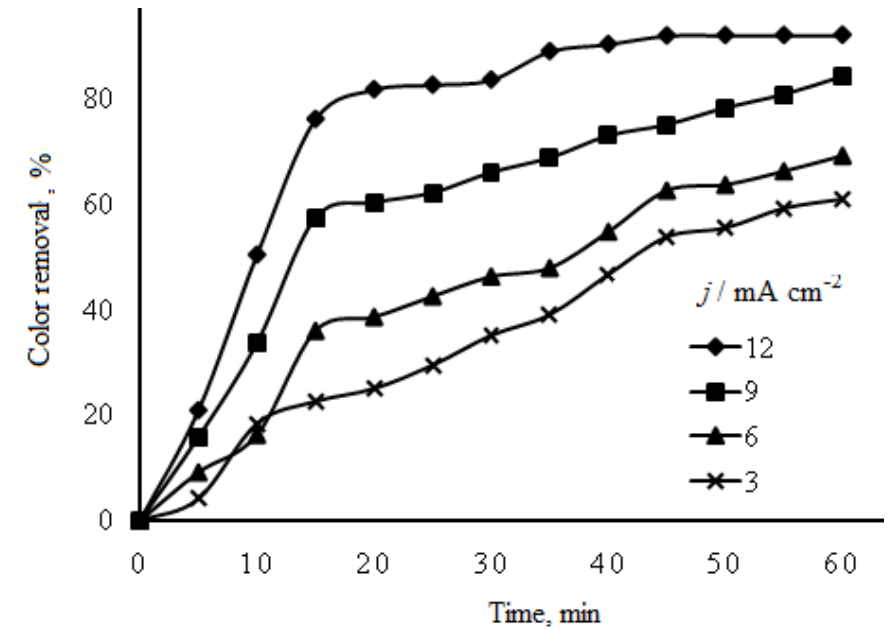

Figure 3. Effect of current density $\left(3-12 \mathrm{~mA} \mathrm{~cm}^{-2}\right)$ on dye removal. Initial dye concentration: $100 \mathrm{mg} \mathrm{L}^{-1}$; NaCl concentration: $9 \mathrm{~g} \mathrm{~L}^{-1} ; \mathrm{pH} 7.0$

\section{Effect of initial dye concentration}

It is seen in Figure 4 that decolorization efficiency falls from 92 to $67 \%$ when the dye concentration was increased from 100 to $500 \mathrm{mg} \mathrm{L}^{-1}$, suggesting that the removal efficiency is inversely proportional to dye concentration. The final $\mathrm{pH}$ of solution and the mass of dissolved nickel foam anodes were nearly independent, while the cell voltage increased slightly with increasing dye concentration. Despite small increase of the cell voltage at a constant current density, the energy consumption shows a strong inverse relationship with dye concentration. When the decolorization rate is inversely proportional to the concentration of dye solution, absorbance of the sample is directly proportional to the concentration of the dye solution. 


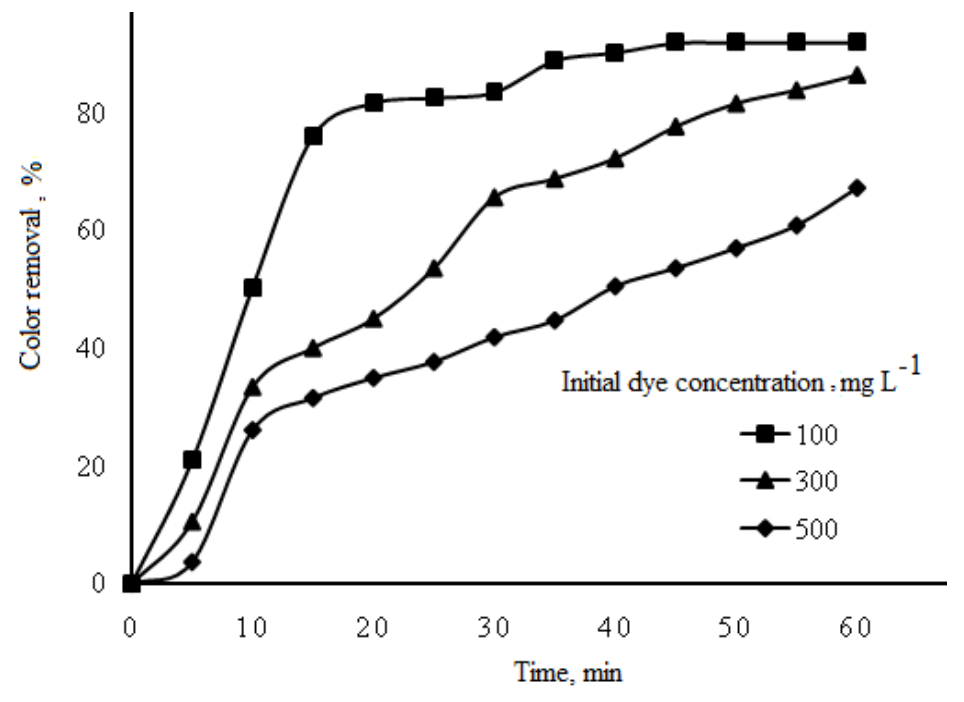

Figure 4. Effect of initial dye concentration (100-500 $\left.\mathrm{mg} \mathrm{L}^{-1}\right)$ on dye removal. Current density: $12 \mathrm{~mA} \mathrm{~cm}^{-2}$; $\mathrm{NaCl}$ concentration: $9 \mathrm{gL}^{-1} ; \mathrm{pH} 7.0$

\section{Conclusion}

Removal of Acid Red 87dye from synthetic wastewater samples by electrocoagulation method was conducted using nickel foam electrode. Batch experiments were performed using nickel foam as anode and stainless steel as cathode. Influence of experimental operating parameters such as initial dye concentration, supporting electrolyte $(\mathrm{NaCl})$ concentration and current density on dye removal efficiency was studied, keeping initial $\mathrm{pH}$ of solution and distance between electrodes constants. The removal efficiency was found proportional to the concentration of supporting electrolyte and current density, but inversely proportional to the initial dye concentration. Up to $92 \%$ dye removal was observed after $40 \mathrm{~min}$ of treatment time for the optimum operating conditions (current density: $12 \mathrm{~mA} \mathrm{~cm}^{-2}$, initial dye concentration: $100 \mathrm{mg} \mathrm{L}^{-1}, \mathrm{NaCl}$ concentration: $9 \mathrm{~g} \mathrm{~L}^{-1}$, initial $\mathrm{pH}$ : 7.0; distance between electrodes: $1 \mathrm{~cm}$ ). Kinetics of the dye removal was found as the first order kinetics. It can be concluded from the present experiments that nickel foam electrode can effectively remove dyes from the wastewater.

\section{References}

[1] J. N. Hakizimana, B. Gourich, M. Chafi, Y. Stiriba, C. Vial, P. Drogui, J. Naja, Desalination 404 (2017) 1-21. https://doi.org/10.1016/i.desal.2016.10.011

[2] A. Kothai, C. Sathishkumar, R. Muthupriya, K. Sivasankar, R. Dharchana, Materials Today: Proceedings 45(2) (2021) 1411-1416. https://doi.org/10.1016/j.matpr.2020.07.094

[3] E. Bazrafshan, H. Moein, F. Kord Mostafapour, S. Nakhaie, Journal of Chemistry 2013 (2013) 640139. http://dx.doi.org/10.1155/2013/640139

[4] D. Kumar, C. Sharma, Journal of Water Resource and Protection 11 (2019) 296-310. https://doi.org/10.4236/jwarp.2019.113017

[5] S. M. Safwat, Journal of Water Process Engineering 34 (2020) 101137. https://doi.org/10.1016/j.jwpe.2020.101137

[6] S. Vasudevan, J. Lakshmi, G. Sozhan, Environmental Science and Pollution Research 19 (2012) 27342744. https://doi.org/10.1007/s11356-012-0773-8

[7] M. Al-Shannag, Z. Al-Qodah, K. Bani-Melhem, M. R. Qtaishat, M. Alkasrawi, Chemical Engineering Journal 260 (2015) 749-756. https://doi.org/10.1016/i.cej.2014.09.035

[8] K. Padmaja, J. Cherukuri, M. Anji Reddy, Journal of Water Process Engineering 34 (2020) 101153. https://doi.org/10.1016/i.jwpe.2020.101153

[9] P. Cañizares, C. Jiménez, F. Martínez, C. Sáez, M. A. Rodrigo, Industrial and Engineering Chemistry Research 46(19) (2007) 6189-6195. https://doi.org/10.1021/ie070059f

[10] F. Ghanbari, M. Moradi, A. Eslami, M. M. Emamjomeh, Environmental Processes 1 (2014) 447-457. https://doi.org/10.1007/s40710-014-0029-3 
[11] T. R. Devlin, M. S. Kowalski, E. Pagaduan, X. Zhang, V. Wei, J. A. Oleszkiewicz, Journal of Hazardous Materials 368 (2019) 862-868. https://doi.org/10.1016/i.jhazmat.2018.10.017

[12] F. Ilhan, K. Ulucan-Altuntas, Y. Avsar, U. Kurt, A. Saral, Frontiers of Environmental Science and Engineering 13 (2019) 73. https://doi.org/10.1007/s11783-019-1152-1

[13] D. Karikaningsih, Y.-H.Huang, Y.-J. Shih, Chemosphere 166 (2017) 184-191. https://doi.org/10.1016/j.chemosphere.2016.09.091

[14] E. Bocos, O. Iglesias, M. Pazos, M. Ángeles Sanromán, Process Safety and Environmental Protection 101 (2016) 34-44. https://doi.org/10.1016/i.psep.2015.04.011

[15] E.Bocos, D. Pérez-Álvarez, M. Pazos, M. C. Rodríguez-Argüelles, M. Ángeles Sanromán, Journal of Chemical Technology and Biotechnology 91(3) (2016) 685-692. https://doi.org/10.1002/jctb.4626

[16] W.Liu, Z. Ai, L. Zhang, Journal of Hazardous Materials 243 (2012)257-264. https://doi.org/10.1016/j.jhazmat.2012.10.024

[17] H. Afanga, H. Zazou, F. E. Titchou, Y.Rakhila, R. A. Akbour, A. Elmchaouri, J. Ghanbaja, M. Hamdani, Sustainable Environment Research 30 (2020) 2. https://doi.org/10.1186/s42834-019-0043-2

[18] F. E. Titchou, H. Afanga, H. Zazou, R. A. Akbour, M. Hamdani, Mediterranean Journal of Chemistry 10(1) (2020) 1-12. http://dx.doi.org/10.13171/mjc10102001201163mh

[19] F. E. Titchou, H. Zazou, H. Afanga, J. El Gaayda, R. A. Akbour, P. V. Nidheesh, M. Hamdani, Journal of Water Process Engineering 41 (2021) 102040. https://doi.org/10.1016/j.jwpe.2021.102040

(C)2021 by the authors; licensee IAPC, Zagreb, Croatia. This article is an open-access article distributed under the terms and conditions of the Creative Commons Attribution license (https://creativecommons.org/licenses/by/4.0/) 